\title{
What do active male brazilian adolescents know about fruits and vegetables?
}

\author{
Rachel Helena Vieira Machado ${ }^{1}$, Iris Iglesia ${ }^{2}$, Carol Anne Hartwick ${ }^{3}$, Roberta Ursaia ${ }^{4}$, \\ Nathalia Fontanezi ${ }^{4}$, Ana Pires ${ }^{3}$, Luís Moreno ${ }^{2,3}$, Mauro Fisberg ${ }^{1,3,4}$
}

DOI: http://dx.doi.org/10.7322/jhgd.122814

\begin{abstract}
:
Objective: To describe and compare data on nutritional awareness regarding FV among adolescents from five Brazilian regions, according to demographics, physical activity levels, screen time and BMI.

Methods: Cross-sectional study with 1.190 males aged 10-12 in five Brazilian regions, enrolled in a football tournament, with parental consent. BMI, weekly physical activity and daily screen time in minutes, awareness of FV recommendations in daily servings and recognition of food groups, home region, and residents of the household were obtained through self-administered questionnaire, adapted from a previously validated tool. ANOVA, Spearman correlation and chi-squared tests were performed, with a significance level of $5 \%$.
\end{abstract}

Results: Analysis showed $29 \%$ of overweight and obesity, less than 2 hours of daily screen time $(70 \%)$ and insufficient levels of weekly physical activity (mean 226 minutes). Most (95\%) lived with parents and with siblings (73\%). About $29 \%$ of the sample were aware of $\mathrm{FV}$ recommendations and $60 \%$ recognized food groups. Awareness was not associated with BMI $(p=0.95)$, home region $(p=0,88)$, physical activity $(p=0.21)$, screen time $(p=0.46)$ or housing characteristics $(p=0.33)$.

Conclusions: Data found on awareness of food groups are consistent with national and international studies, suggesting patterns of poor awareness worldwide. To our knowledge, there are no other Brazilian reports of level of awareness on recommendations of FV in this age group. The importance of behavioral interventions is acknowledged for stimulating healthy habits, which renders the results useful for the development of educational activities for this age group in Brazil.

Keywords: adolescents, fruits and vegetables, eating habits, awareness/knowledge, physical activity.

\section{INTRODUCTION}

The consumption of fruits and vegetables (FV) assists in preventing overweight development, given its fiber content and influence on satiety and overall food intake amounts. In adolescence, it encourages a lifestyle consistent with its particular nutritional requirements. ${ }^{1}$ Considering the Brazilian current overweight prevalence in adolescence $(20 \%)^{2-3}$, the trend towards obesity over the past 40 years $^{3}$ and the impact of early obesity on the adult nutritional state ${ }^{2}$, governmental guidelines recommend a minimum FV consumption of $400 \mathrm{~g} /$ day (five servings) for the overall population..$^{4-7}$ Prevalence of adequate consumption in adolescence, however, is reported as less than $30 \%$ in Brazil. $6,8-11,12-15$

Availability at home, exposure, family habits, formal education and income, media, school catering and awareness influence FV intake in adolescence. ${ }^{2,8,10,11,14} \mathrm{At}$ this age, one is capable of better absorbing the contents of interventions and managing food choices compared with

1 PENSI Institute - Sabará Children's Hospital/José Luiz Egydio Setúbal Foundation (Av Angélica 1968 cj 71 - Higienópolis/SP 01228-200 - Brazil).

2 GENUD (Growth, Exercise, Nutrition and Development) research group, Facultad de Ciencias de la Salud, Universidad de Zaragoza, Instituto Agroalimentario de Aragón (IA2), Instituto de Investigación Sanitaria de Aragón (IIS Aragón), Zaragoza. (Edif. del SAI - Servicio de Apoyo a la Investigación, C/ Pedro Cerbuna 12 - 50009 Zaragoza - Spain).

3 Danone Institute International (Route Departamentale 128 - 91767 - Palaiseau - France)

4 Federal University of São Paulo (Av Borges Lagoa 1080 cj 603 - VI Clementino/SP - 04038-002 - Brazil). Corresponding author: Rachel HV Machado - Email: rhvmachado@gmail.com

Suggested citation: Machado RHV, Iglesia I, Hatwickc CA, Ursaia R, Fontanezi N, Pires A, et al. What do active male brazilian adolescents know about fruits and vegetables? J Hum Growth Dev. 2016; 26(3): 316-322. Doi: http://dx.doi.org/10.7322/jhgd.122814

Manuscript submitted: Sep 6 2016, accepted for publication Sep 142016. 
children, and, in order to take effective action, it is important to assess the level of nutritional awareness. ${ }^{1,16-17}$ The objective of this study, therefore, is to describe and compare data on nutritional awareness regarding FV among adolescents aged 10-12 from five Brazilian regions, according to demographic characteristics, physical activity levels, screen time and Body Mass Index (BMI).

\section{METHODS}

\section{Design and sample selection}

The study is part of the Brazilian multicentric survey entitled "The Fit Food Study", implemented during the Brazilian national phase of the Danone Nations Cup (DNC). The study was approved by the PENSI Institute Ethics Committee (Brazil), and aimed at investigating eating habits, awareness and overweight prevalence of participants in each country, as well as developing an intercultural nutritional education program.

As the study capitalized on the opportunity offered by the DNC event, no formal sample size calculations have been undertaken. Hence, population consisted of a cross sectional convenience sampling performed in five of the six regions where the competition was held: São Paulo (SP), Rio de Janeiro (RJ) and Minas Gerais (MG, all southwest of Brazil); Rio Grande do Sul (RS, south of Brazil) and the Federal District (DF). Ceará (Northeast of Brazil) was the only region not included in the study, due to logistic impediments.

The study was performed from May to June of 2014, with teams of male adolescents aged 10 to 12 years old. Inclusion criteria consisted of age, enrollment in the tournament and parental written consent. All enrolled were approached by the study $(n=4.464)$, yielding a final $\mathrm{n}$ of 1.190 (due to lack of written consent or unavailability of the children), with $1.2 \%(\mathrm{n}=15)$ from RJ, $70.9 \%(\mathrm{n}=$ 844) from SP, 10.2\% $(n=122)$ from $M G, 7.5 \%(n=89)$ from the DF, $10.1 \%(n=120)$ from RS.

\section{Data collection}

A self-administered questionnaire with multiplechoice qualitative and semi-quantitative questions was used, adapted from the validated tool designed for the European ENERGY study ${ }^{18}$, to be used with physically active adolescents of the same age group. The following self-reported information were selected from the surveys: anthropometric data (weight in $\mathrm{kg}$, height in $\mathrm{cm}$; used for calculation and analysis of the BMI/age according to WHO (2007) ${ }^{19}$, residents of the household (parents or caretakers, and siblings), physical activity duration per week and screen time per day (TV and video gaming), and both in minutes. Use of self-reported height and weight for calculation of corresponding BMI has been proven to be valid and effective worldwide with different age groups. ${ }^{20-22}$

To assess the awareness of FV recommendations, question responses were regarded with six possible answers. The " 5 servings of FV / day" alternative was deemed adequate ${ }^{7}$ and categorized as 'correct' or 'incorrect'. To assess awareness of food groups, an illustrated question with a picture of the Brazilian food pyramid was used, ${ }^{23-24}$ with numbers 1-5 indicating the different food groups, which should be related to gaps with names of various types of food. The complete sequence corresponding to the groups was deemed adequate, and categorized as the 'correct' or 'incorrect'. The food pyramid used followed current recommendations of the Brazilian Ministry of Health by the time of the study design. ${ }^{24}$

\section{Statistical analysis}

Despite the absence of sample size calculations in advance of the data collection, retrospective power calculations were undertaken to ensure that any conclusions drawn are appropriate. Post Hoc analysis of sample calculation reports a 99\% observed power, assuming effect size of $18 \%$. Statistical analysis was performed using SPSS v21 software. Descriptive analysis was performed through proportion distribution (\%) for categorical variables and mean \pm standard deviation for continuous variables. The comparison between physical activity duration and levels of awareness was performed by ANOVA test. For comparisons between awareness and home regions, BMI (classification), screen time and demographic characteristics, the chi-squared test was performed, with a significance level of 5\%. The Spearman correlation was used to test associations between awareness and the variables, and correlations above $r=0,61$ considered suitable for deeper analysis.

\section{RESULTS}

The profile of the sample consists of normal BMI (59\%), less than 2 hours of daily screen time (70\%) and average 226 minutes of weekly physical activity (equivalent to 30 minutes per day, deemed insufficient). ${ }^{25}$ The maximum reported duration of physical activity per week was 300 minutes, so no one achieved expected levels in this population. Most adolescents were living with parents (96\%) and siblings (74\%). Demographic characteristics are described in Table 1, below.

Adolescents' awareness of recommendations regarding FV servings did not vary according to geographical region ( $\mathrm{p}=0.88)$, BMI $(\mathrm{p}=0.95)$, physical activity patterns $(p=0.21)$, total screen time $(p=0.46)$ or housing characteristics $(\mathrm{p}=0.33)$, as seen in Table 2 . The proportion of correct answers was lower than $29 \%$ of valid responses. Regarding food source recognition according to groups, there is a higher percentage of correct answers, close to $60 \%$ of the valid responses. There was no association, however, between the correct answers and the analyzed variables (Table 1 ).

Correlations between awareness of FV recommendations and food groups and the remaining variables were all considered weak $(r<0,4)$, with the exception of the variable 'living with siblings', which showed a medium correlation with FV recommendation awareness $(r=0,50)$. Since results were all below cut points for strong or excellent associations, logistic regression analysis to verify factors associated to awareness was considered unnecessary. Results of all correlations are presented in Table 3. 
Table 1: Demographic characteristics of the study population: male adolescents aged 10-12 participating in the Brazilian Danone Nations Cup, 2014

\begin{tabular}{|c|c|c|}
\hline Variables & Mean (n) & \pm sd or $\%$ \\
\hline \multicolumn{3}{|l|}{ BMI $\left(\mathrm{kg} / \mathrm{m}^{2}\right)$} \\
\hline & $18.48(\mathrm{~N}=700)$ & $\begin{array}{c} \pm 2.62(\mathrm{p} 2516.57 ; \mathrm{P} 75) \\
19.99\end{array}$ \\
\hline \multicolumn{3}{|l|}{ BMI (WHO 2007) (19) $n=700$} \\
\hline Underweight & $N=85$ & $12.1 \%$ \\
\hline Normal weight & $N=412$ & $58.9 \%$ \\
\hline Overweight & $N=161$ & $23 \%$ \\
\hline Obesity & $N=42$ & $6 \%$ \\
\hline \multicolumn{3}{|l|}{ Screen time (hours/day) $n=1150$} \\
\hline$<2$ h/day & $N=807$ & $70.2 \%$ \\
\hline$>2 \mathrm{~h} /$ day & $N=343$ & $29.8 \%$ \\
\hline \multicolumn{3}{|l|}{ Physical activity $n=1154$} \\
\hline Minutes/week & $226(n=1154)$ & $\pm 88.4(p 25150 ; p 75300)$ \\
\hline$\leq 210 \mathrm{~min} /$ week (30min/day) & $N=450$ & $39 \%$ \\
\hline $210-400 \mathrm{~min} /$ week (30-60 $\mathrm{min} /$ day $)$ & $N=704$ & $61 \%$ \\
\hline \multicolumn{3}{|l|}{ Living situation } \\
\hline \multicolumn{3}{|l|}{ Adult supervision $(n=1190)$} \\
\hline At least one or both parents & $N=1147$ & $96.4 \%$ \\
\hline Relatives or caregivers & $N=43$ & $3.6 \%$ \\
\hline \multicolumn{3}{|l|}{ Siblings $(n=1167)$} \\
\hline Living with one or more siblings & $N=859$ & $73.6 \%$ \\
\hline Only child or not living with siblings & $N=308$ & $26.4 \%$ \\
\hline
\end{tabular}

Table 2: Distribution of FV awareness according to nutritional status variables, home region and physical activity patterns among male adolescents aged 10-12 participating in the Brazilian Danone Nations Cup, 2014

\begin{tabular}{|c|c|c|c|c|c|c|}
\hline \multirow[b]{3}{*}{ Variables } & \multicolumn{6}{|c|}{ Nutritional awareness } \\
\hline & \multicolumn{3}{|c|}{ FV recommend } & \multicolumn{3}{|c|}{ Food sources } \\
\hline & correct answers & $\mathbf{N}$ & $\mathbf{p}$ & $\%$ correct answers & $\mathbf{N}$ & $\mathbf{p}$ \\
\hline Total & 28.8 & 1147 & - & 60.3 & 1157 & - \\
\hline & 26.2 & \multicolumn{5}{|c|}{ BMI (WHO 2007) (19)* } \\
\hline Healthy & 28.9 & 401 & & 76.8 & 328 & \\
\hline Overweight & 29.6 & 152 & & 83.1 & 136 & \\
\hline Obesity & 28.6 & 42 & & 80 & 35 & \\
\hline Total & & 679 & & & 566 & \\
\hline \multicolumn{7}{|l|}{ State* } \\
\hline RJ & 28.6 & 14 & 0.88 & 100 & 9 & 0.09 \\
\hline SP & 29.6 & 817 & & 74.8 & 658 & \\
\hline MG & 27.1 & 118 & & 71.4 & 84 & \\
\hline DF & 25 & 84 & & 73.1 & 67 & \\
\hline RS & 27.2 & 114 & & 80.7 & 109 & \\
\hline Total & & 1147 & & & 927 & \\
\hline \multicolumn{7}{|l|}{ Screen time (hours/ day) } \\
\hline$<2 \mathrm{~h} /$ day & 28.9 & 783 & 0.46 & 74.7 & 625 & 0.24 \\
\hline$>2 \mathrm{~h} /$ day & 28.4 & 335 & & 77.1 & 280 & \\
\hline Total & & 1118 & & & 905 & \\
\hline \multicolumn{7}{|l|}{ Living situation } \\
\hline \multicolumn{7}{|l|}{ Adult supervision ( $n=1190$ ) } \\
\hline At least one or both parents & 28.9 & 320 & 0.33 & 75.6 & 680 & 0.12 \\
\hline Relatives or caregivers & 24.4 & 10 & & 64.3 & 18 & \\
\hline \multicolumn{7}{|l|}{ Siblings $(n=1167)$} \\
\hline Living with one or more siblings & 29.8 & 246 & 0.052 & 76.2 & 515 & 0.27 \\
\hline Only child or not living with siblings & 24.7 & 74 & & 73.9 & 176 & \\
\hline \multicolumn{7}{|c|}{ Physical activity (min/ week) - mean (n)** } \\
\hline & Correct answers & \pm sd & & Incorrect answers & \pm sd & $\mathbf{p}$ \\
\hline FV recommendations ( $\mathrm{n}=1111$ ) & $225(n=322)$ & 88 & & $226(n=789)$ & 88 & 0.21 \\
\hline Food sources $(n=897)$ & $227(n=676)$ & 88 & & $221(n=221)$ & 91 & 0.44 \\
\hline
\end{tabular}

*Chi-squared test - Yates ** ANOVA test 
Table 3: Correlations between sample characteristics and awareness in male adolescents aged 10-12 participating participating in the Brazilian Danone Nations Cup, 2014

\begin{tabular}{lc} 
Variable & R (Spearman) \\
Y = Awareness of FV recommendations & \\
BMI Healthy/underweight & -0.009 \\
Home region & 0.012 \\
Screen time & 0.021 \\
Living situation (with parents) & -0.19 \\
Living situation (with siblings) & -0.50 \\
Y = Recognition of food groups & \\
BMI Healthy/underweight & -0.054 \\
Home region & 0.007 \\
Screen time & 0.026 \\
Living situation (with parents) & -0.045 \\
Living situation (with siblings) & -0.023 \\
\hline
\end{tabular}

\section{DISCUSSION}

The results reported reflect the profile of adequate BMI an insufficient levels of physical activity, according to the minimum recommendation of 60 minutes per day $^{25}$, in addition to general poor awareness of FV recommendations in the assessed regions, highlighting the need for focused educational activities for this age group. It has also been noted that the appropriate FV consumption frequency reported in literature (under $30 \%)^{6,8-11}$ is similar to awareness levels regarding recommendations reported in this study (29\%). The impact of awareness on FV consumption of this population is not to be inferred, nevertheless, as the instrument had no questions regarding intake frequency of such foods. It is believed that the poor awareness of FV is widespread in the assessed parts of the country, given the homogeneous frequencies found.

Brazilian literature has reported results similar to those presented for food groups' awareness (60\% accuracy) and overall healthy eating: Gonçalves et al ${ }^{25}$ have reported a mean baseline score of 55\% accuracy (pre-intervention) for awareness in Brazilian physically active adolescents aged 12-15. Alves et al (2009) ${ }^{26}$ and Assis et al $(2014)^{23}$ have observed about 50\% pre-intervention accuracy in similar studies with adolescents from MG. Toral $(2010)^{17}$, in a qualitative analysis with 25 adolescents aged 15+ in Brasília (DF), has reported accounts of appropriate general notions of healthy eating, including FV intake (without defining recommendations, however). Nevertheless, there were no specific national data regarding $\mathrm{FV}$ awareness for comparison with the results herein.

Internationally, an assessment conducted in Italy ${ }^{27}$ with children and adolescents aged 4-16 has displayed percentages of correct responses between 37.5\% and 56\% (significantly better among adolescents compared to children). In Europe, the HELENA study ${ }^{28}$ has found percentages ranging $50-70 \%$ for adequate nutritional awareness among adolescents aged 13-16. These studies, however, do not discriminate specific data related to FV aware- ness. A study conducted in Iran ${ }^{16}$ with 4.700 children and adolescents aged 14-18 has found an awareness score of $26 \%$ for food groups. A Chinese study with students aged $12-14^{29}$, which assessed awareness of FV functions, has displayed correct answers at $16 \%$. Data from the NHANES disclosed in $2012{ }^{30}$ reports prevalence of awareness in the North-American nutritional education program (which stimulates the appropriate FV consumption) in less than $45 \%$ of the adolescents, and less than $30 \%$ for awareness concerning intake recommendations for food groups in general. Similar results suggest that adolescents worldwide have poor levels of awareness for proper nutrition.

It has also been reported that awareness was not influenced by any of the variables tested. Similar accounts were found in the literature on the lack of association between awareness and levels of physical activity, age, socioeconomic status, gender ${ }^{16,25,28}$ and BMI, ${ }^{28,30}$ except for the Italian study ${ }^{27}$ which showed a slightly higher awareness score (1 point total score) in healthy subjects compared to overweight ones $(\mathrm{p}<0.003)$. Studies are consistent on the grounds that food consciousness is related to environmental and family factors, besides state of motivation itself, and not to organic factors. ${ }^{8,10-11,17}$ Among these external factors, the association with living with parents and/or siblings was not expected either, since it is suggested that formal education and parental income, cohabitation time and family routine (not assessed in this analysis) are the major influential factors, rather than just the cohabitation characteristics. ${ }^{14}$

The data reported in this analysis is useful for possible inferences about the population's eating habits, as poor awareness of food and nutrition reflects on the consolidation of attitudes and food choices, even under interference from environmental factors hitherto mentioned. ${ }^{16-17,25,27}$ As a diagnostic instrument, they support the planning of focused action plans, given ample evidence of the positive impact of educational interventions on FV intake. ${ }^{25,31-32}$ For this population, it is also important to combine the baseline awareness data to further investigation into motivational state (pre-contemplation, contemplation, decision, action) and environmental characteristics ${ }^{17}$ of adolescents, so that the right strategies are established, including working with both parents and the community in which they live.

The study has limitations, such as the absence of questions regarding $\mathrm{FV}$ intake and environmental factors in the questionnaire (which limit comparisons). Considering the Fit Food Study as a pilot project, the limitations were considered for the adaptation and further validation of the instrument to be used in future editions. As strengths, the sample size and the use of awareness proportion stand out as diagnostic for improving the nutritional education program developed in subsequent stages of the study, increasing the focus of educational activities on concepts of recommendations, functions and food sources of FV. Additionally, the study gives valuable and new contribution on information about awareness focused on FV recommendations, specifically, whereas other national and international studies consider awareness of healthy eating in general in their publications. 


\section{CONCLUSIONS}

The adolescents surveyed mostly live with parents and siblings, displaying adequate BMI and daily screen time, insufficient levels of physical activity, and poor awareness of FV recommendations. The data found on general awareness of food groups are consistent with national and international studies, suggesting patterns of worldwide poor awareness. There was no association of awareness with home region, BMI, physical activity levels and screen time or home environment. The importance of nutritional education is acknowledged for stimulating healthy habits, which renders the results useful for the development of educational activities for this age group in Brazil.

\section{ACKNOWLEDGMENTS}

To Mr Romain Perraut, in charge of the logistic organization of the soccer tournament (Danone Nations Cup - DNC), who provided logistical support to enable surveys and educational activities. We also thank Mr Paulo Tiago S. Muliterno for help with translation of the manuscript to english, and all the volunteers who participated in the project: Amanda B. Neto, Ana Carolina L. Rocha, Ana Elisabeth N Sato, Carolina GV Souza, Caroline O Lima, Evelyn Hasbani, Fernanda RS Buscarati, Jessica CB Delgado, Joice S Silva, Julia FF Guimarães, Larissa A L Oliveira, Larissa H Ishigai, Maressa Santos, Maria Fernanda M Burlamaqui, Marielen A Freitas, Rafael N Santos, Renata S Kochi, Simone M Futigami and Thiago R Oliveira.

\section{Financial Support}

The study was coordinated by the Federal University of São Paulo (Brazil), in partnership with the University of Zaragoza (Spain), and funded by the Danone International Institute. Children 10-12 years old were approached through participation in an international soccer tournament (Danone Nations Cup - DNC). The funder has contributed to the study design and conduct of the study, but not to the analysis of data, interpretation of findings or the preparation of the manuscript.

\section{Conflict of interest}

- Authors Ana Pires and Carol Anne Hartwick are employees of the industry.

- The PI of the project conferences in events such as - Abbott, CPW, EMS, Danone, Nestlé, Nutrociencia, PICME, Sanofi, Wyeth; scientific board member of Danone Institute International, Danone Research, Mondelez. Supports research projects at Abbott, CNPq, Coca-Cola, CPW, Danone Institute International, Danone Research, Fapesp, Fap Unifesp, Nestlé.

- Authors have no participation in food, nutrition or farmaceutical companies, and there is no influence of any company in any of the projects, conferences or publications conducted.

\section{Authorship}

Rachel Helena Vieira Machado - main researcher, carried out the study, participated in the design, data analysis and preparation on manuscript.

Iris Iglesia - assisted in carrying out the study, data analysis and preparation on manuscript.

Carol Anne Hartwick - assisted in formulating research questions, in the study design and preparation on manuscript.

Roberta Ursaia and Nathalia Fontanezzi - both assisted in data collection and analysis.

Ana Pires - assisted in carrying out the study and preparation on manuscript.

Luis Moreno - supervised and assisted all phases of the study.

Mauro Fisberg - supervised and assisted all phases of the study (Project PI).

\section{Ethical Standards disclosure}

This study was conducted according to the guidelines laid down in the Declaration of Helsinki and all procedures involving human subjects/patients were approved by the PENSI Institute Ethical Committee (Brazil). Written informed consent was obtained from all subjects/patients

\section{REFERENCES}

1. Maia ER, Lima Junior JF, Pereira JS, Eloi AC, Gomes CC, Nobre MMF. Validação de metodologias ativas de ensino-aprendizagem na promoção da saúde alimentar infantil. Rev Nut. 2012;25(1):79-88. DOI: http:// dx.doi.org/10.1590/S1415-52732012000100008

2. Rede Nacional Primeira Infância (RNPI). Mapeamento da Ação Finalística "Criança com Saúde" Obesidade na primeira infância. Projeto Observatório Nacional da primeira infância. Fortaleza: Instituto da Infância; RNPI; 2014.

3. Instituto Brasileiro de Geografia e Estatística (IBGE). Pesquisa nacional de saúde 2013: perceção do estado de saúde, estilos de vida e doenças crônicas: Brasil, grandes regiões e unidades da federação. Rio de Janeiro: IBGE; 2014.

4. Brasil. Ministério da Saúde. Guia alimentar para a população brasileira. $2^{\text {nd }}$ ed. Brasília: 2014.

5. Castanho GKF, Marsola FC, Mclellan KCP, Nicola M, Moreto F, Burini RC. Consumo de frutas, verduras e legumes associado à Síndrome Metabólica e seus componentes em amostra populacional adulta. Ciênc. saúde coletiva. 2013;18(2): 385-92. DOI: http://dx.doi.org/10.1590/S1413-81232013000200010

6. Ciochetto CR, Orlandi SP, Vieira MFA. Consumo de frutas e vegetais em escolares da rede pública no Sul do Brasil. ALAN. 2012; 62(2): 172-78. 
7. Sociedade Brasileira de Pediatria (SBP). Obesidade na infância e adolescência: manual de Orientação. Rio de Janeiro: Departamento de Nutrologia; 2008.

8. Monticelli FDB, Souza JMP, Souza SB. Adolescent students' consumption of fruit, greens and vegetables. J Hum Growth Dev. 2013; 23(3): 331-7. DOI: http://dx.doi.org/10.7322/jhgd.69509

9. Toral N, Slater B, Cintra IP, Fisberg M. Comportamento alimentar de adolescentes em relação ao consumo de frutas e verduras. Rev Nutr. 2006;19(3):331-340. DOI: http://dx.doi.org/10.1590/S141552732006000300004

10. Bigio RS, Verly Junior E, Castro MA, César CLG, Fisberg RM, Marchioni DML. Determinantes do consumo de frutas e hortaliças em adolescentes por regressão quantílica. Rev Saúde Pública. 2011; 45(3): 448-56. DOI: http://dx.doi.org/10.1590/S0034-89102011005000023

11. Rieth MA, Moreira MB, Fuchs FD, Moreira LB, Fuchs SC. Fruits and vegetables intake and characteristics associated among adolescents from Southern Brazil. Nutr J. 2012; 11: 95. DOI: http://dx.doi. org/10.1186/1475-2891 - 11-95

12. Dumith SC, Muniz LC, Tassitano RM, Hallal PC, Menezes AM. Clustering of risk factors for chronic diseases among adolescents from Southern Brazil. Prev Med. 2012;54(6):393-396. DOI: http://dx.doi.org/10.1016/j. ypmed.2012.03.014

13. Mello MVFA, Andrade RF, Otero LM, Cárdenas AMC, Silva SR. Risk factors associated with diabesity in primary school students in the Amazon region of Brazil. Invest Educ Enferm. 2013; 31(3): 433-41.

14. Muniz LC, Zanini RV, Schneider BC, Tassitano RM, Feitosa WMN, González-Chica DA. Prevalência e fatores associados ao consumo de frutas, legumes e verduras entre adolescentes de escolas públicas de Caruaru, PE. Ciênc Saúde Coletiva. 2013; 18(2): 393-404. DOI: http://dx.doi.org/10.1590/S141381232013000200011

15. Souza AM, Pereira RA, Yokoo EM, Levy RB, Sichieri R. Alimentos mais consumidos no Brasil: Inquérito Nacional de Alimentação 2008-2009. Rev Saúde Pública. 2013;47 (Supl 1): 190S-9. DOI: http://dx.doi. org/10.1590/S0034-89102013000700005

16. Naeeni MM, Jafari S, Fouladgar M, Heidari K, Farajzadegan Z, Fakhri M, et al. Nutritional knowledge, practice, and dietary habits among school children and adolescents. Int J Prev Med. 2014; 5 (Suppl 2): S171-8.

17. Toral N, Conti MA, Slater B. A alimentação saudável na ótica dos adolescentes: percepções e barreiras à sua implementação e características esperadas em materiais educativos. Cad Saúde Pública. 2009; 25(11): 2386-94. DOI: http://dx.doi.org/10.1590/S0102-311X2009001100009

18. van Stralen MM, te Velde SJ, Singh AS, Bourdeaudhuij I, Martens MK, van der Sluis M, et al. EuropeaN Energy balance Research to prevent excessive weight Gain among Youth (ENERGY) project: Design and methodology of the ENERGY cross-sectional survey. BMC Public Health. 2011;11:65. DOI: http://dx.doi. org/10.1186/1471-2458-11-65

19. World Health Organization (WHO). Child growth standards and the identifi cation of severe acute malnutrition in infants and children. Switzerland: Unicef; 2009.

20. Ekström S, Kull I, Nilsson S, Bergström A. Web-Based Self-Reported Height, Weight, and Body Mass Index Among Swedish Adolescents: a validation study. J Med Internet Res. 2015; 17(3): e73. DOI: http:// dx.doi.org/10.2196/jmir.3947

21. Pérez A, Gabriel KP, Nehme EK, Mandell DJ, Hoelscher DM. Measuring the bias, precision, accuracy, and validity of self-reported height and weight in assessing overweight and obesity status among adolescents using a surveillance system. Int J Behav Nutr Phys Activity. 2015; 12(Suppl1):S2. DOI: http://dx.doi. org/10.1186/1479-5868-12-S1-S2

22. Carvalho AM, Piovezan LG, Selem SSAC, Fisberg RM, Marchioni DML. Validação e calibração de medidas de peso e altura autorreferidas por indivíduos da cidade de São Paulo. Re. Bras Epidemiol. 2014; 17(3): 735-46. Doi: http://dx.doi.org/10.1590/1809-4503201400030013

23. Assis MM, Penna LF, Neves CM, Mendes APCC, Oliveira RMS, Pereira Netto M. Avaliação do conhecimento nutricional e comportamento alimentar após educação alimentar e nutricional em adolescentes de Juiz de Fora - MG. HU Rev. 2014; 40(3-4): 135-43.

24. Brasil. Ministério da Saúde. Secretaria de Atenção à Saúde. Departamento de Atenção Básica. Guia alimentar para a população brasileira: promovendo a alimentação saudável. Brasília: Ministério da Saúde; 2008.

25. Gonçalves CB, Nogueira JAD, Costa THM. The food pyramid adapted to physically active adolescents as a nutrition education tool. Rev Bras Ciênc Esporte. 2014; 36(1): 29-44. DOI: http://dx.doi.org/10.1590/ S0101-32892014000100003

26. Alves L, Melo DHC, Melo JF. Análise do conhecimento nutricional de adolescentes, pré e pós atividade educativa. Extensão. 2009; 8(2): 68-79.

27. Grosso G, Mistretta A, Turconi G, Cena H, Roggi C, Galvano F. Nutrition knowledge and other determinants of food intake and lifestyle habits in children and young adolescents living in a rural area of Sicily, South Italy. Public Health Nutr. 2012; 16(10): 1827-36. DOI: http://dx.doi.org/10.1017/S1368980012003965 
28. Kersting M, Sichert-Hellert W, Vereecken CA, Diehl J, Béghin L, De Henauw S, et al. Food and nutrient intake, nutritional knowledge and diet-related attitudes in European adolescents. Int J Obes (Lond). 2008;32(Suppl 5):S35-41. DOI: http://dx.doi.org/10.1038/ijo.2008.181

29. Wang D1, Shi Y, Chang C, Stewart D, Ji Y, Wang Y, et al. Knowledge, attitudes and behaviour regarding nutrition and dietary intake of seventh-grade students in rural areas of Mi Yun County, Beijing, China. Environ Health Prev Med. 2014; 19(3): 179-86. DOI: http://dx.doi.org/10.1007/s12199-013-0372-4

30. Wojcicki M, Heyman B. Adolescent nutritional awareness and use of food labels: Results from the national nutrition health and examination survey. BMC Pediatr. 2012; 12:55. DOI: http://dx.doi.org/10.1186/14712431-12-55.

31. Silveira JA, Taddei AAC, Guerra H, Nobre RC. A efetividade de intervenções de educação nutricional nas escolas para prevenção e redução do ganho excessivo de peso em crianças e adolescentes: uma revisão sistemática. J Pediatr. 2011; 87(5): 382-92. DOI: http://dx.doi.org/10.2223/JPED.2123

32. Bessems KM, van Assema P, Martens MK, Paulussen TG, Raaijmakers LG, de Rooij M, et al. Healthier food choices as a result of the revised healthy diet programme Krachtvoer for students of prevocational schools. Int J Behav Nutr Phys Act. 2012;9:60. DOI: http://dx.doi.org/10.1186/1479-5868- 9-60

This article is distributed under the terms of the Creative Commons Attribution 4.0 International License (http://creativecommons.org/licenses/by/4.0/), which permits unrestricted use, distribution, and reproduction in any medium, provided you give appropriate credit to the original author(s) and the source, provide a link to the Creative Commons license, and indicate if changes were made. The Creative Commons Public Domain Dedication waiver (http://creativecommons.org/publicdomain/zero/1.0/) applies to the data made available in this article, unless otherwise stated.

\section{Resumo}

Objetivo: Identificar os padrões alimentares (PA) e sua relação com segurança alimentar e estado nutricional de pré-escolares.

Método: Estudo transversal com 308 crianças entre 24 e 48 meses de idade atendidas em creches municipais de Taubaté, São Paulo, Brasil. O consumo alimentar foi avaliado por questionário de frequência alimentar e analisado por meio de seus componentes principais. O estado nutricional foi avaliado pelo indicador IMC/idade e a situação de insegurança alimentar (IA) foi classificada pela pontuação da Escala Brasileira de Insegurança Alimentar.

Resultados: Identificou-se cinco PA: "Ocidental", "Frutas, verduras e legumes", "Prudente", "Lácteo" e "Tradicional". Os pré-escolares com padrão "Ocidental" tem menores chances (OR:0,51; IC95\%:0,27-0,98) de estarem em IA moderada e grave; contudo, a qualidade da alimentação está comprometida, caracterizando o IA leve. Enquanto as crianças com dieta "Tradicional" estão fortemente relacionadas às famílias que recebem benefício social e ao excesso de peso infantil $(p<0,05)$.

Conclusões: PA "Ocidental" e "Tradicional" são qualitativa e quantitativamente inadequados, independente da condição de renda familiar e escolaridade materna. Assim, ações públicas que combatam padrões alimentares desfavoráveis à saúde são urgentes para prevenção de doenças crônicas.

Palavras-chave: padrão alimentar, segurança alimentar e nutricional, excesso de peso, pré-escolares, consumo de alimentos. 